\title{
Pengaruh Kepemimpinan, Budaya Organisasi Dan Motivasi Terhadap Kinerja Karyawan Dalam Mengembangkan Bisnis Periklanan Pada PT Bangun Selaras
}

\author{
Cipta Nur Hidayat ${ }^{1}$, Nurminingsih ${ }^{2}$,Mariati Tamba ${ }^{3}$ \\ Program Studi Administrasi Bisnis Program Magister Universitas Respati Indonesia \\ email: cipta_8@yahoo.com,nings@urindo.ac.id,mariati.tamba@yahoo.com
}

\begin{abstract}
ABSTRAK
PT Bangun Selaras adalah perusahaan yang bergerak dalam bidang advertising atau reklame, jasa konstruksi, elektrikal atau mekanikal dan interior contractor. PT Bangun Selaras memanjakan pelanggan dan memberikan layanan advertising satu atap yang terbaik dari ide, perencanaan gambar, produksi, instalasi sampai pajak reklame. Tujuan peneltian ini adalah untuk mengetahui kepemimpinan, budaya organisasi dan motivasi terhadap kinerja karyawan. Penelitian ini merupakan penelitian kuantitatif. Data diperoleh melalui kuesioner dengan skala likert yang disebarkan kepada responden pada karyawan PT Bangun Selaras sebanyak 100 orang. Penentuan sample responden dilakukan secara total sampling. Analisis data menggunakan Structural Equation Modeling-Partial Least Square (SEM-PLS) dengan program SmartPLS 3. Hasil penelitian menunjukkan bahwa kepemimpinan memiliki pengaruh dan signifikan terhadap Kinerja karyawan, budaya organsiasi memiliki pengaruh dan signifkan terhadap kinerja karyawan, motivasi memiliki pengaruh dan signifikan terhadap kinerja karyawan Saran untuk pimpinan perusahaan perlu mempertahanakan dan meningkatkan kinerja karyawan dengan memikirkan strategi dan identifikasi proses bisnis dalam kondisi covid-19, bergerak cepat dalam mengambil peluang pasar yang memberikan keuntungan bagi perusahaan dan dorongan internal dan eksternal agar kemampuan karyawan dapat memberikan kemampuan yang lebih baik.
\end{abstract}

Kata Kunci:Kepemimpinan, Budaya Organisasi, Motivasi, Kinerja Karyawan 


\begin{abstract}
PT Bangun Selaras is a company engaged in advertising or advertising, construction services, electrical or mechanical and interior contractors. PT Bangun Selaras pampers customers and provides the best one-stop advertising services from ideas, image planning, production, installation to billboard taxes. The purpose of this research is to determine the leadership, organizational culture and motivation for employee performance. This research is a quantitative research. Data obtained through a questionnaire with a likert scale distributed to respondents to employees of PT Bangun Selaras as many as 100 people. Determination of the sample of respondents is done by total sampling. Data analysis used Structural Equation Modeling-Partial Least Square (SEM-PLS) with the Smart-PLS 3 program. The results showed that leadership has a significant influence on employee performance, organizational culture has a significant and significant influence on employee performance, motivation has an influence and is significant on employee performance. Suggestions for company leaders need to maintain and improve employee performance by thinking about strategies and identifying business processes in the covid-19 conditions, moving quickly in taking market opportunities that provide benefits for the company and internal and external encouragement so that employee abilities can provide better abilities.
\end{abstract}

Keywords : Leadeership, Organizational Culture, Motivation, employee performance. 


\section{PENDAHULUAN}

\begin{abstract}
Persaingan industri yang sejenis harus mempunyai keunggulan kompetitif yang sangat sulit ditiru, hal tersebut dapat diperoleh dari karyawan yang produktif, inovatif, kreatif selalu bersemangat dan loyal.
\end{abstract} Karyawan yang memenuhi kriteria seperti itu hanya akan dimiliki melalui penerapan konsep dan teknik manajemen sumber daya manusia yang tepat dengan semangat kerja yang tinggi serta pemimpin yang efektif dan lingkungan kerja yang mendukung. Faktor-faktor yang dapat digunakan untuk meningkatkan kinerja karyawan, diantaranya motivasi dan kepemimpinan.

\begin{tabular}{lrr}
\multicolumn{2}{c}{ Pentingnya } & pemimpin \\
dalam sebuah & organisasi \\
terungkap $\quad$ dalam & suatu
\end{tabular} pernyataan berikut: bahwa untuk menunjang keberhasilan fungsi manajemen dalam organisasi tentunya membutuhkan seorang pemimpin yang dapat melaksanakan tugas atau fungsi manajemen (Fikri, 2008). Seorang pemimpin adalah pribadi yang memiliki kecakapan khusus dengan atau tanpa pengangkatan formal dapat mempengaruhi kelompok yang dipimpinnya, untuk melakukan usaha bersama mengarah kepada pencapaian tujuan tertentu (Herispon, 2010).

Kepemimpinan dan motivasi merupakan kunci utama dalam manajemen yang memegang peran strategis dan penting dalam kelangsungan hidup perusahaan. Motivasi kerja merupakan perilaku dan faktorfaktor yang mempengaruhi pegawai untuk berperilaku terhadap pekerjaannya. PT
Bangun Selaras memulai karirnya dalam bidang periklanan sejak tergabung dengan beberapa perusahaan periklanan dengan menangani jasa periklanan untuk beberapa client dari perusahaan swasta, nasional hingga instansi pemerintah. Namun di perusahaan tersebut banyak mengalami kendala, yakni terkait dengan kepemimpinan yang kurang mampu mengelola sumber daya manusia dan tanggung jawab karyawan yang belum maksimal, minat karyawan yang rendah sehingga akan mengganggu jalannya perusahaan.

Dalam perkembangan bisnis periklanan perusahaan PT. Bangun Selaras telah berhasil mendapatkan banyak pelanggan perusahaan besar di Indonesia seperti Bank Permata, Bank Mandiri, Bank DKI dan banyak perusahaan lainnya yang telah bekerja sama cukup lama dalam pembuatan produksi iklan yang efektif dan memaksimalkan media digital untuk pemasaran, promosi dan branding produk yang menunjang kemajuan bisnis perusahaan perusahaan yang menjadi pelanggan,

\section{Kepemimpinan}

Kepemimpinan merupakan suatu faktor yang menentukan tercapai atau tidaknya tujuan suatu instansi, dengan kepemimpinan yang baik, proses manajeman akan berjalan lancar dan pegawai bergairah melaksanakan tugas-tugasnya. Gairah kerja, produktivitas kerja, dan proses manajeman suatu 


\section{Budaya Organisasi}

Budaya organisasi adalah seperangkat nilai, kepercayaan, falsafah dan pemahaman yang terpola menjadi asumsi-asumsi dasar yang dikembangkan dan dijadikan dasar dalam berperilaku, berpikir, membuat aturan-aturan, pengambilan keputusan serta berbagai masalah organisasional lainnya. Dalam hal ini Budaya Organisasi adalah nilai-nilai dominan yang disebarluaskan didalam perusahaan dan diacu sebagai filosofi kerja karyawan yang indikatornya adalah kesadaran diri, keagresifan, kepribadian dan performa.

\section{Motivasi Kerja}

Motivasi adalah
kegiatan mendorong atau
memberi semangat kerja pada
seseorang, agar mau bekerja
secara optimal guna mencapai
tujuan perusahaan, sehingga
dapat diharapkan setiap
karyawan dapat bekerja keras
serta antusias untuk mencapai
tujuan perusahaan yang telah
ditetapkan sebelumnya. Dalam
hal ini Motivasi adalah proses
mempengaruhi atau mendorong
dari luar terhadap seseorang
atau sekelompok kerja agar
mereka mau melaksanakan
sesuatu yang telah ditetapkan
yang indikatornya adalah
dorongan internal dan dorongan
eksternal.

\section{Kinerja Karyawan}

Kinerja karyawan memiliki peran yang sangat penting dalam melaksanakan setiap pekerjaan dengan harapan tercapainya tujuan perusahaan. Tujuan perusahaan akan sulit untuk dicapai apabila banyak pegawai yang tidak menyelesaikan pekerjaan dengan baik dan tidak tepat waktu hal ini akan merugikan perusahaan. Dalam hal ini Kinerja Karyawan adalah hasil kerja yang diperoleh seseorang atau sekelompok orang dalam suatu perusahaan, wewenang dan tanggung jawab masingmasing dalam upaya mencapai tujuan organisasi yang indikatornya adalah kualitas pekerjaan, kuantitas pekerjaan, tanggung jawab dan kemampuan kerja.

\section{METODE PENELITIAN}

jenis penelitian kuantitatif. Penelitian ini dilakukan di PT Bangun Selaras yang beralamat di J1 Murai2 No.69, Sawah Lama, Kec.Ciputat, Kota Tanggerang Selatan, Banten 15413. Populasi dalam dalam penelitian ini adalah seluruh karyawan PT Bangun Selaras. Sampel dalam penelitian ini adalah populasi penelitian yakni seluruh karyawan yang berjumlah 100 yang ditetapkan menjadi sampel sehingga teknik pengambilan sampel yang tepat adalah total sampling. Pengumpulan diperoleh melalui data primer dan data sekunder. Analisis data dan pengujian hipotesis menggunakan Structural Equation Model (SEM) dengan menggunakan software partial least square (PLS). Adapun tahap-tahap pengujiannya outer dan inner model meliputi uji Convergent Validity, Discriminant Valdity, Composite Reliability, R-square dan path koefisien. 
Berdasarkan penelitian

HASIL PENELITIAN DAN PEMBAHASAN yang telah dilakukan outer model penelitian adalah sebagai berikut

\section{Gambar 1. Outer Model}

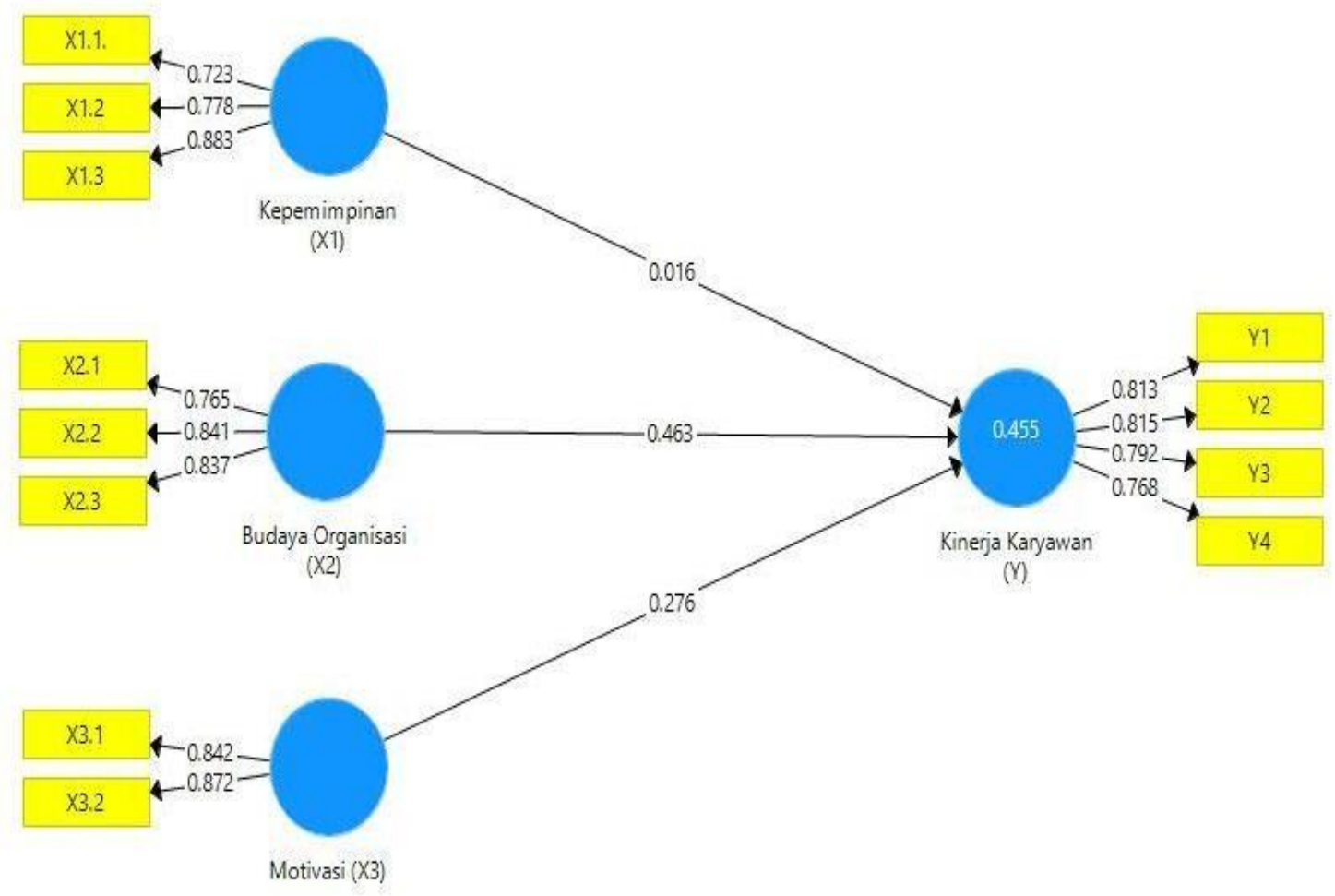

Sumber : SmartPLS, 2020

Berdasarkan hasil uji validitas variabel kepemimpinan, budaya organisasi, motivasi dan kinerja karyawan didapatkan hasil bahwa 33 item pernyataan dinyatakan valid karena nilai outer loading $>0,5$. Hal tersebut berarti butir-butir pernyataan dalam variabel kepemimpinan, budaya organisasi, motivasi, dan kinerja karyawan dinyatakan valid dan layak digunakan sebagai instrumen penelitian.

Uji reliabilitas menunjukkan sejauh mana suatu alat ukur yang dapat memberikan hasil yang relative sama apabila dilakukan pengukuran kembali pada subyek yang sama. Uji reliabilitas dapat dilihat pada Tabel 1 sebagai berikut 
Tabel 1

Uji Reliabilitas

\begin{tabular}{|l|l|c|c|c|}
\hline & $\begin{array}{l}\text { Cronbach's } \\
\text { Alpha }\end{array}$ & rho_A & $\begin{array}{c}\text { Average } \\
\text { Composite } \\
\text { Reliability }\end{array}$ & $\begin{array}{c}\text { Variance } \\
\text { Extracted } \\
\text { (AVE) }\end{array}$ \\
\hline Kepemimpinan (X1) & 0.712 & 0.741 & 0.839 & 0.636 \\
\hline Budaya Organisasi (X2) & 0.748 & 0.755 & 0.856 & 0.664 \\
\hline Motivasi (X3) & 0.739 & 0.743 & 0.847 & 0.734 \\
\hline Kinerja Karyawan (Y) & 0.810 & 0.814 & 0.875 & 0.636 \\
\hline
\end{tabular}

Sumber : Data diolah SEM - SmartPLS

Hasil pengolahan uji

reliabilitas pada variabel kepemimpinan, budaya organisasi, motivasi dan kinerja karyawan didapatkan nilai Composite Reliability $(C R)$ untuk semua konstruk lebih besar dari 0,7 yang menunjukkan bahwa semua konstruk pada model diestimasi memenuhi kriteria discriminant validity. Selanjutnya Menurut Hair et., al (1998), direkomendaskan nilai Average Variance Extracted $(A V E)$ untuk semua konstruk harus lebih besar dari 0,5. menunjukkan bahwa nilai akar dari $A V E$ untuk setiap konstruk adalah lebih besar dari 0,5 atau lebih. Dengan demikian hasil pengujian Average Variance Extracted (AVE) semua reliable. Berdasarkan hasil seluruh uji instrument dari uji validitas dan reliabilitas dinyatakan bahwa semua butir pernyataan memenuhi persyaratan untuk dipakai dalam instrument penelitian.

Berdasarkan tabel 1 
Selanjutnya Pengujian Model Struktural (Inner Model)

\section{Gambar 2. Inner Model}

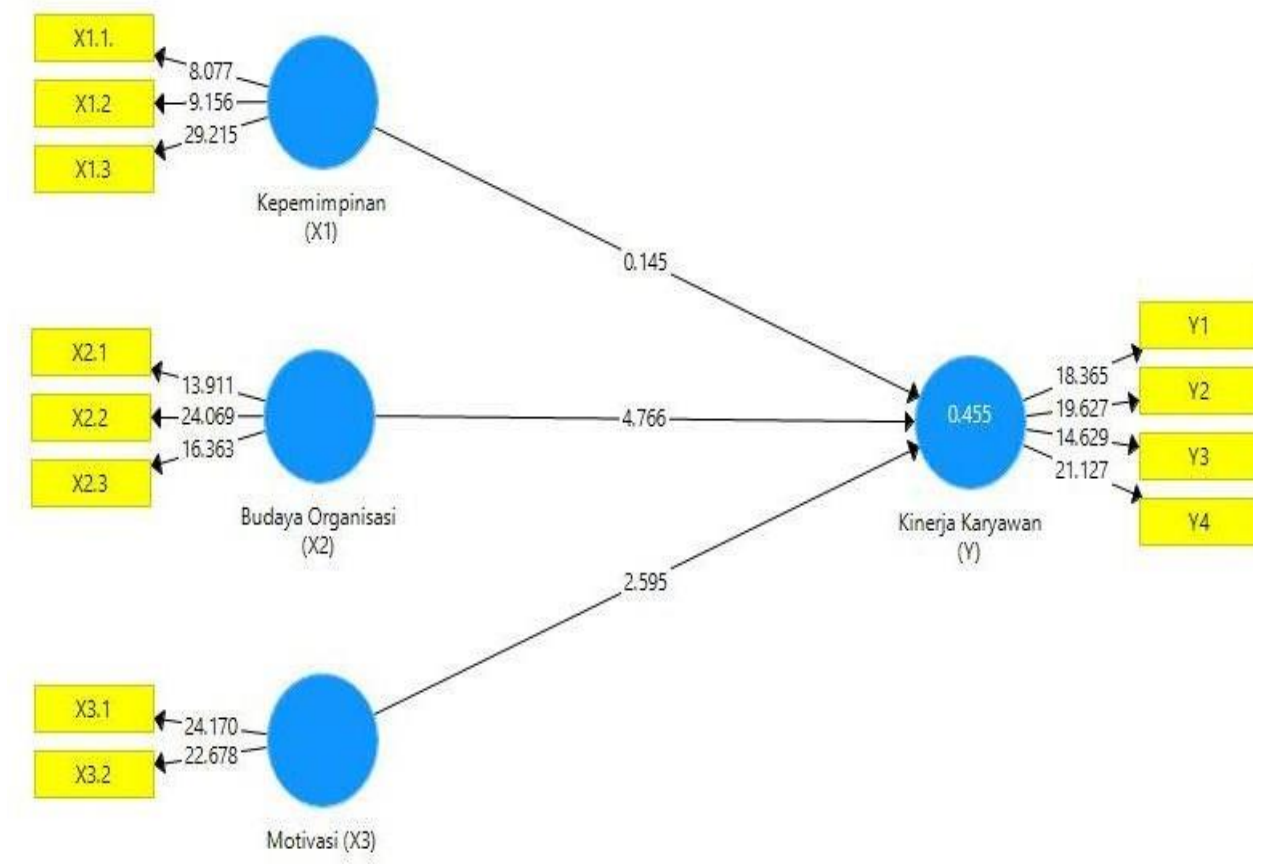

Sumber : SmartPLS, 2020

Hasil pengolahan data variabel kepemimpinan, budaya organisasi, motivasi kerja, dan kinerja karyawan dapat dilihat pada tabel 5.8 dibawah ini:

Tabel 2

Hasil Uji Hipotesis

\begin{tabular}{|l|c|c|c|c|c|}
\hline & $\begin{array}{c}\text { Original } \\
\text { Sample } \\
\text { (O) }\end{array}$ & $\begin{array}{c}\text { Sample } \\
\text { Mean } \\
\text { (M) }\end{array}$ & $\begin{array}{c}\text { Standard } \\
\text { Deviation } \\
\text { (STDEV) }\end{array}$ & $\begin{array}{c}\text { T Statistics } \\
\text { (O/STDEV) }\end{array}$ & $\begin{array}{c}\text { P } \\
\text { Values }\end{array}$ \\
\hline $\begin{array}{l}\text { Kepemimpinan } \\
\text { (X1) - Kinerja } \\
\text { Karyawan (Y) }\end{array}$ & 0.316 & 0.022 & 0.108 & 2.145 & $\mathbf{0 . 0 0 5}$ \\
\hline $\begin{array}{l}\text { Budaya } \\
\text { Organisasi (X2) } \\
\text { - Kinerja } \\
\text { Karyawan (Y) }\end{array}$ & 0.463 & 0.461 & 0.097 & 4.766 & $\mathbf{0 . 0 0 0}$ \\
\hline $\begin{array}{l}\text { Motivasi (X3)- } \\
\text { - Kinerja } \\
\text { Karyawan (Y) }\end{array}$ & 0.276 & 0.286 & 0.106 & 2.595 & $\mathbf{0 . 0 1 0}$ \\
\hline
\end{tabular}

Sumber : Data diolah SEM-Smart-PLS 
1)

\section{Pembuktian Hipotesis 1 : Kepemimpinan berpengaruh signifikan terhadap kinerja karyawan} Tabel 5.13 menunjukkan hasil Original Sample $=0,316, \mathrm{~T}$ Statistic $=2,145, \mathrm{P}$ Values $=$ $0,005 \quad(<0,05)$. Hal ini menunjukkan bahwa pengaruh antara kepemimpinan terhadap kinerja karyawan adalah signifikan. Demikian H1 dalam penelitian ini diterima. Artinya kepemimpinan berpengaruh signifikan terhadap kinerja karyawan.

1) Pembuktian Hipotesis 2 : Budaya Organisasi berpengaruh signifikan terhadap kinerja karyawan Tabel 5.13 menunjukkan hasil Original Sample $=0,463, \mathrm{~T}$ Statistic $=4,766, \mathrm{P}$ Values $=$ $0,000 \quad(<0,05)$. Hal ini menunjukkan bahwa pengaruh antara budaya organisasi terhadap kinerja karyawan adalah signifikan.
Demikian H1 dalam penelitian ini diterima. Artinya budaya organisasi berpengaruh signifikan terhadap kinerja karyawan.

\section{2) Pembuktian 3 :Motivasi} berpengaruh signifikan terhadap kinerja karyawan. Tabel 5.13 menunjukkan hasil Original Sample $=0,276, \mathrm{~T}$ Statistic $=2,595, \mathrm{P}$ Values $=$ $0,010 \quad(<0,05)$. Hal ini menunjukkan bahwa pengaruh antara motivasi terhadap kinerja karyawan adalah signifikan. Demikian H1 dalam penelitian ini diterima. Artinya motivasi berpengaruh signifikan terhadap kinerja karyawan.

Analisis pengaruh determinasi dalam analisis SEM digunakan untuk mengetahui besar kontribusi dari variabel eksogen terhadap variabel endogen dapat dilihat dari adjusted R square-nya.

Tabel 3

R Square

\begin{tabular}{|l|c|c|}
\hline & R Square & R Square Adjusted \\
\hline Kinerja Karyawan & 0.455 & 0.438 \\
\hline
\end{tabular}

Sumber : Data Diolah SEM - SmartPLS 3

Berdasarkan tabel diatas dapat di ketahui bahwa nilai $\mathrm{R}$ Square Kinerja Karyawan = 0.455. Hal ini menunjukkan bahwa besar pengaruh kepemimpinan, budaya organisasi dan motivasi kerja, terhadap kinerja karyawan sebesar $45,5 \%$.

\section{PEMBAHASAN}

Kepemimpinan berpengaruh terhadap Kinerja Karyawan

Hasil penelitiaan pada PT bangun selaras proses manageman berjalan sangat baik dan karyawan sangat bergairah 
kepemimpinan di PT bangun selaras memiliki pengaruh yang tinggi terhadap kinerja karyawannya.

Hasil penelitian ini sesuai dengan penelitian yang telah dilakukan oleh para peneliti terdahulu yaitu Abdul Syukur dan Edy Supriyono dan Yohana Kus Suparwati (2019), Imelda Andayani dan Satria Tirtayasa (2019), Moh. Imron (2018), Catur Windaryadi (2018), Eggy Girniawa, Badia Perizade, Bambang Bemby.S Bernadette Robiani (2019), Sri Rahayuningsih (2018) yang membuktikan terdapat pengaruh signifikan Kepemimpinan terhadap Kinerja Karyawan.

\section{Budaya Organisasi berpengaruh terhadap Kinerja Karyawan}

Budaya organisasi di PT bangun selaras sangat baik terlihat dari karyawan yang memiliki kepuasan bekerja dan dapat bekerja sama dalam menyelesaikan pekerjaannya, rasa kekeluargaan atara karyawan. Sangat megutamakan kualitas hasil pekerjaan dan berinovasi menemukan hal yang baru seperti pada masa pandemic covid 19 saat ini, Jadi dari penelitian yang dilakukan menunjukan bahwa Budaya organisasi di PT bangun selaras memiliki pengaruh yang tinggi terhadap kinerja karyawannya.

Hasil penelitian ini sesuai dengan penelitian yang telah dilakukan oleh para peneliti terdahulu yaitu Abdul Syukur dan Edy Supriyono dan Yohana Kus Suparwati (2019), Imelda Andayani dan Satria Tirtayasa (2019), Moh. Imron (2018), Catur Windaryadi (2018), Sri Rahayuningsih (2018) yang membuktikan terdapat pengaruh signifikan Budaya Organisasi terhadap Kinerja Karyawan.

\section{Motivasi berpengaruh terhadap Kinerja Karyawan}

Hasil penelitian pada PT bangun selaras, motivasi kerja karyawan yang sangat tinggi terlihat pada tanggung jawab dalam menyelesaikan pekerjaan yang sangat baik dan pendapatan gaji dan kesejahteraan yang di terima seluruh karyawan sangat mencukupi di atas upah minimum rata rata perusahaan periklanan, menimbulkan peningkatan kinerja karyawan PT Bangun Selaras yang lebih optimal, sehingga dapat bersaing dengan perusahaan bisnis periklanan lainnya dan lebih maju dan berkembang seperti saat ini, Jadi dari penelitian yang dilakukan menunjukan bahwa motivasi di PT bangun selaras memiliki pengaruh yang tinggi terhadap kinerja karyawannya.

Hasil penelitian ini sesuai dengan penelitian yang telah dilakukan oleh para peneliti terdahulu yaitu Imelda Andayani dan Satria Tirtayasa (2019) dan Sri Rahayuningsih (2018) yang membuktikan terdapat pengaruh signifikan Motivasi terhadap Kinerja Karyawan.

\section{KESIMPULAN DAN SARAN}

\section{Kesimpulan}

1. Pengaruh antara kepemimpinan terhadap kinerja karyawan adalah signifikan. Demikian H1 dalam penelitian ini diterima. Artinya kepemimpinan berpengaruh positif dan 
2. Pengaruh antara motivasi terhadap kinerja karyawan adalah signifikan. Demikian H3 dalam penelitian ini diterima. Artinya motivasi berpengaruh positif dan signifikan terhadap kinerja karyawan.

\section{Saran}

1. PT Bangun Selaras perlu mempertahankan dan meningkatkan kinerja karyawan , didalam masa pandemic covid 19 pemimpin perusahaan harus arief dan bijaksana dan memberikan arahan yang jelas disaat mengeluarkan kebijakan WFH (Work From Home) yang kemungkinan besar akan menurunkan semangat bekerja karyawan, dengan memikirkan strategi dan indentifikasi proses bisnis yang tidak memungkinkan dilakukan secara teleworking karena harus membutuhkan akses fisik secara langsung kedalam system kerja nya.

2. PT Bangun Selaras perlu mempertahankan dan meningkatkan budaya organisasi agar dapat bergerak cepat dalam mengambil peluang-peluang pasar, terutama pada masa pandemic covid 19 saat ini yang sangat mempengaruhi dunia perusahaan periklanan, dengan adanya kebijakan WFH setiap pekerja didorong untuk memikirkan cara agar dapat bekerja secara efektif dan efesien walaupun tidak bertatap muka secara langsung dengan rekan kerja lainnya, implementasi WFH memerlukan kepercayaan dan kebebasan berinovasi kesadaran diri setiap pegawai yang akan memberikan keuntungan terbesar bagi perusahaan baik dari sisi produktivitas, kreativitas dalam mencapai keberhasilan perusahaan yang lebih besar.

3. PT Bangun Selaras perlu mempertahankan dan meningkatkan motivasi terhadap seluruh karyawannya baik secara dorongan internal dan dorongan eksternal agar karyawan dapat memberikan kemampuan yang lebih baik terhadap pekerjaannya perusahaan harus selalu memantau mengenai kebijakan pemerintah pusat maupun daerah terhadap upaya penangan virus corona, untuk menjamin keberlangsungan operasional dan layanan perusahaan memerlukan rencana mengenai bisnis keberlanjutan bisnis yang dimutakhirkan dengan memberikan edukasi keterampilan virtual. 


\section{DAFTAR PUSTAKA}

Abdul Syukur, Edy Supriyono, Yohana Kus Suparwati. $2019 . \quad$ Pengaruh Kepimpinan, Komunikasi Organisasi Dan Budaya Organisasi Terhadap Kinerja Pegawai Sekretariat DPRD Kabupaten Tegal

Anyim dan Chidi, 2012.

"Motivation and

Employees

Performance in the

Public and Private

Sectors in Nigeria", International Journal of

Business

Administration,

Volume 3 No. 1 Januari

2012.Nigeria :

University of Lagos.

Catur Windaryadi. 2018.

Pengaruh Kepemimpinan

dan Budaya Organisasi

Terhadap Kinerja Pegawai.

Eggy Girniawa, Badia Perizade, Bambang Bemby.S, Bernadette Robiani (2019). Pengaruh Kepemimpinan, Budaya Organisasi, Dan Kompetensi Terhadap Kinerja Pegawai Kementerian Agraria Dan Tata Ruang / Bpn Kantor Pertanahan Kota Palembang.

Edison, Emron. Yohny anwar, Imas komariyah. (2016). Manajemen Sumber Daya Manusia. Bandung: Alfabeta.

Fauzi, Muhammad. 2016. Pengaruh Budaya Organisasi dan Kepuasan
Kerja Terhadap Kinerja

Karyawan dengan

Komitmen organisasi

Sebagai Variabel

Intervening. Journal of Management Vol. 2 No. 3 Maret 2016.

Fikri.2008.Pengaruh Tipe Kepemimpinan dan Budaya Organisasi terhadap Motivasi Kerja Pegawai Kecamatan Lowokwaru Kota Malang. Jurnal Aplikasi Manajemen: JAM. Vol. 6, No. 1. Halaman 98103:Malang

Ghozali, Imam. 2011. Aplikasi Analisis Multivariate Dengan Program IBM SPSS 19.

Semarang: UNDIP

Haryoko, Sapto dan Iskandar. 2008. Metodologi Penelitian Pendidikan dan Sosial (kuantitatif dan Kualitatif). Jakarta: Gaung Persada Press

Herispon.2010. Profil Setengah Pemimpin Serta Dampaknya Dalam Manajemen.

Jurnal Ekonomi Bisnis V ol. 1 No.1 Halaman 93-100.

Imelda Andayani, Satria Tirtayasa. 2019. Pengaruh Kepemimpinan, Budaya Organisasi, Dan Motivasi Terhadap Kinerja Pegawai.

Kartono, Kartini. 2013. Pemimpin dan Kepemimpinan, Apakah Kepemimpinan Abnormal itu?. Cetakan Kesembilanbelas. PT. Raja 
Mohyi. 1999. Teori dan Perilaku

Organisasi. Malang: UMM Press.

Mulyadi. 2015 Manajemen Sumber Daya Manusia

Mangkunegara, AA Anwar Prabu. 2009.

Manajemen Sumber Daya Manusia.

Bandung

: PT. Remaja Rosdakarya.

Notoatmodjo, S. 2010.

Metodologi Penelitian

Kesehatan. Jakarta: Rineka Cipta

Onanda, Belly. 2015. The Effect

of Motivatio On Job Performance

A Case Study of

KCB Coast Region.

Journal Of Scientific and

Reseach publication. Vol.

5, Issue 9 ISSN 2250-3153

Rahadi, Dedi Rianto. 2010. Manajemen Kinerja Sumber Daya Manusia. Malang: Tunggal Mandiri Publishing

Rahmawati, Novita Rizqi. 2013. Pengaruh Gaya Kepemimpinan dan Motivasi Kerja Terhadap Kinerja Karyawan. Jurnal Universitas

Muhammadiyah Surakarta.

Ridwan. 2012. Analisis Gaya Kepemimpinan Situasional Terhadap Kinerja Karyawan. Jurnal Otonomi Vol. 1 No. 3 Juli 2012
Robbins. 2010. Perilaku Organisasi. Jakarta: Salemba Empat

Sarita, Jena. 2009. Pengaruh Gaya Kepemimpinan Situasional Motivasi Kerja Locus Of Control Terhadap Kepuasan Kerja dan prestasi Kerja Auditor. Jurnal Universitas Sriwijaya 3-9 November 2009.

Sedarmayanti. 2009. Tata Kerja dan Produktivitas Kerja. Bandung: Mandar Maju ,2013,

Manajemen Sumber

Daya Manusia,

Bandung: Refika

Aditama.

Sekaran, Uma. 2014. Metodologi Penelitian

Untuk Bisnis (Research

Methods for Business) Buku

1 Edisi 4. Jakarta: Salemba

Empat.

Shahzad, Fakhar. 2012. Impact of Organizasional Culture on Organizational performance : An Overview.

Interdisciplinary Journal of Contemporary Reseach in Business Vol 3 No 9 2012

Rivai. 2015. Manajemen Sumber Daya

Manusia untuk Perusahaan 
Shahzadi, Irum. 2014. Impact of Employee Motivation on Employee Performance. Journa of business and Management. ISSN 22221905 Vol. 6 No 232014

Siswanto, \& Agus Sucipto . 2008. Teori \& Prilaku

Organisasi.

Malang;Malang Press

UIN.

Sunyoto, Danang, 2013, Manajemen

Sumber Daya

Manusia, Cet. 1, CAPS (Center For Academic Publising

Service), Yogyakarta.

Sri Rahayuningsih. 2018. Pengaruh Kepemimpinan, Motivasi Kerja, Budaya Organisasi Terhadap Kinerja Pegawai, Dengan Komitmen Organisasi Sebagai Variabel Intervening (Studi Kasus di Instansi $X)$

Sutikno, Sobry M. 2014. Pemimpin dan Gaya Kepemimpinan, Edisi Pertama. Lombok: Holistica

Sugiyono. 2015. Metode Penelitian pendidikan Pendekatan Kuantitatif Kualitatif dan $R \& D$.Bandung:Alfabeta.

Sutrisno, $\quad$ Eddy. 2010. Manajemen Sumber Daya Manusia. Edisi Kesatu Kencana Prenada Media Group:Jakarta.
Thahir, Arifin. 2014. Buku Ajar Perilaku Organisasi. Sleman: Deepublish.

Thoha, Miftah. 2006.

Kepemimpinan dalam

Manajemen. PT. Raja

Grafindo Persada:Jakarta.

Timple. 2015. Manajemen

Sumber Daya Manusia. Bumi

Aksara. Jakarta. Wahjosumidjo.

2014. Peran Budaya

Organisasional Untuk

Meningkatkan Kepuasan

Kerja dan Kinerja

Karyawan.Benefit.Vol.6.No.2.Dese mber.

Wardani. 2009. Riset Sumber Daya

Manusia. Jakarta : PT. Gramedia Pustaka Utama.

Wukir, 2013,

Manajemen Sumber

Daya Manusia Dalam

Organisasi Sekolah,

Cetakan I, Multi

Presindo, Yogyakarta.

Yukl, Gary, .2010. Kepimpinan dalam Organisasi, Edisi Kelima. Jakarta: PT. Indeks. 